УДК 343.3

DOI https://doi.org/10.32837/pyuv.v1i4(29).406

\author{
I. O. Сна \\ orcid.org/0000-0003-0090-5005 \\ аспірант кафедри крилінально-правових дисииплін \\ Харківського національного педагогічного університету \\ ілені Г. С. Сковороди
}

\title{
САНКЦІЇ ЗА ЗЛОЧИНИ ПРОТИ ОСНОВ НАЦІОНАЛЬНОЇ БЕЗПЕКИ УКРАЇНИ: ОКРЕМІ ЗАКОНОМІРНОСТІ ТА ПРОБЛЕМИ ПОБУДОВИ
}

Нині Україна перебуває на важкому шляху захисту й збереження свого суверенітету та незалежності. В умовах зовнішньої агресії проти нашої держави особливого значення набуває механізм захисту національної безпеки Батьківщини. Цей механізм може вдало функціонувати й забезпечити виконання поставлених перед ним цілей тільки за умови його належного правового регулювання. Одним зі способів захисту національної безпеки України є встановлення кримінальної відповідальності за злочини, що зазіхають на самі підвалини існування нашої державності й суспільства. Пеналізація, у свою чергу, неможлива без установлення чіткої та належно вибудуваної системи санкцій за злочини певного виду. Тому предметом наукового розгляду є система санкцій за злочини проти основ національної безпеки України.

Метою наукової статті є визначення закономірностей побудови санкцій за злочини проти основ національної безпеки, виявлення проблемних моментів їх правової регламентації та пропонування можливих шляхів їх вирішення.

3 огляду на важливість відносин у сфері забезпечення протидії злочинам проти основ національної безпеки України, дослідженню проблематики цих видів злочину присвячувалася досить велика кількість наукових робіт. Із них можна виділити наукові розвідки, проведені такими вченими, як В.А. Ліпкан, Ю.Є. Максименко, В.М. Желіховський, О.П. Дзьобань, Л.В. Мошняга, О.Ф. Бантишева, О.В. Шамара, Ю.В. Луценко, М.А. Рубащенко, О.С. Власюк, О.А. Чувакова, Н.С. Кончук.

Але, незважаючи на нібито велику кількість наукових праць, присвячених проблематиці дослідження злочинів проти основ національної безпеки України, значна кількість питань залишилася без належного розгляду, особливо це стосується особливостей призначення покарання за злочини такого роду.

Одним із векторів, який вимагає наукової розвідки в ракурсі призначення покарання за злочини проти основ національної безпеки України, $€$ виокремлення особливостей формування санкцій відповідних статей, у межах яких у подальшому буде призначатися покарання.

У сучасній кримінально-правовій літературі неодноразово ставилося питання про проблемність науково-теоретичного обгрунтування побудови санкцій. Розроблення вказаного питання загалом уважається недосконалим і вимагає більш глибокого дослідження цього правового явища [6, с. 588]. Перш ніж досліджувати особливості побудови системи санкцій за злочини проти основ національної безпеки України, необхідно чітко визначити методологічний підхід, за яким це буде здійснюватися.

У літературі зазначається, що конструктивні характеристики санкцій статей (частин статті) Особливої частини Кримінального кодексу (далі - КК) України передбачають аналіз альтернативності, ступеня визначеності, кумулятивності. В Особливій частині КК України переважають альтернативні санкції, які, у свою чергу, можуть бути диференційованими за кількістю видів основних покарань. За ступенем визначеності можуть бути виокремлені абсолютно визначені та відносно визначені санкції. У цьому разі варто зазначити, що в Особливій частині КК України представлено лише відносно визначені санкції, серед яких наявна певна кількість відносно визначених санкцій з елементами абсолютної визначеності. В Особливій частині КК України представлені як кумулятивні, так і некумулятивні санкції.

Так, розділ I «Злочини проти основ національної безпеки України» Особливої частини КК України з моменту прийняття до початку 2014 року мав статус єдиного розділу в Особливій частині КК, до якого не внесено жодних змін. Але у 2014 році ситуація в країні під впливом зовнішньої агресії різко загострилася, у зв'язку з чим відбулося поглиблення рівня пеналізації за декількома напрямами: 1) у санкцію ч. 3 ст. 110 КК України введено довічне позбавлення волі; 2) підвищено нижні межі санкцій багатьох статей або частин статей(ст. 110 , ч. 1 ст. 111 , ст. ст. 113, 114 КК України); 3) підвищено верхні межі санкцій усіх частин ст. 110 КК України; 4) усі санкцій статей цього розділу переведено в розряд потенційно кумулятивних шляхом передбачення додаткового факультативного покарання у вигляді конфіскації майна (ст. ст. 109-114 КК України); 5) скорочено перелік можливих основних видів покарань в окремих альтернативних санкціях (ч. ч. 1, 2 ст. 110 КК України). Крім того, у розділі I з'явилися дві принципово нові норми: ст. 110-2 
«Фінансування дій, вчинених з метою насильницької зміни чи повалення конституційного ладу або захоплення державної влади, зміни меж території або державного кордону України» і ст. 114-1 «Перешкоджання законній діяльності Збройних Сил України та інших військових формувань» [1, с. 65].

Деякі автори, підтверджуючи необхідність поглиблення відповідальності за вказані злочини, зазначають, що одним із правових заходів (напрямів) забезпечення основ національної безпеки України $€$ якраз кримінально-правове забезпечення цих основ, яке належить до охоронних правових напрямів у цій сфері. Як відомо, КК має своїм завданням правове забезпечення охорони прав і свобод людини та громадянина, власності, громадських порядку й безпеки, довкілля, конституційного устрою України від злочинних посягань, забезпечення миру й безпеки людства, а також запобігання злочинам, для чого КК визначає, які суспільно небезпечні діяння є злочинами та які покарання застосовуються до осіб, що їх учинили (ст. 1 КК України). Якщо бути більш точним, то КК встановлює не лише злочинність діяння, а і його караність та інші кримінально-правові наслідки діяння (ч. 3 ст. 3 КК України), адже мова йде не тільки про покарання, що застосовуються до особи, визнаної винною в учиненні злочину, а й про інші кримінально-правові наслідки вчиненого (у т. ч. звільнення від відповідальності, звільнення від покарання чи його відбування) та інші заходи кримінально-правового характеру як щодо фізичної особи (примусове лікування, примусові заходи медичного характеру, спеціальна конфіскація, примусові заходи виховного характеру), так і щодо юридичної особи (штраф, конфіскація, ліквідація) [5]. Саме тому санкції як нормативна регламентація застосування форм реалізації кримінальної відповідальності в усій їі різноманітності підлягають обов'язковому науковому дослідженню та розробленню.

Проведений нами аналіз положення чинного КК України показав, що розділ I КК України «Злочини проти основ національної безпеки» містить у загальній кількості 19 санкцій, з них: 1) 3 санкції є заохочувальними й передбачають можливість звільнення від кримінальної відповідальності осіб, які вчинили окремі злочини проти основ національної безпеки (ч. 5 ст. 110-2 КК України, ч. 2 ст. 111 КК України, ч. 2 ст. 114 КК України); 2) альтернативних - 3 (ч. ч. 2, 3 ст. 109 КК України, ст. 112 КК України), 3) безальтернативних - 13. Безальтернативні санкції як єдине покарання, що може бути призначене, установлюють позбавлення волі на певний строк. Як альтернатива цьому виду покарання в інших санкціях виступає обмеження волі - у ч. ч. 2,3 ст. 109 КК України, у ст. 112 КК України - довічне позбавлення волі.

Із зазначених 19 санкцій не виявлено жодної абсолютно визначеної санкції. При цьому лише одна з досліджуваних санкцій має ознаки часткової визначеності, оскільки як альтернативу позбавленню волі на певний строк передбачає покарання у вигляді довічного позбавлення волі, яке є покаранням безстроковим і не передбачає судового розгляду в строках його призначення. Звідси $з$ тих санкцій, що не є заохочувальними (3 випадки), усі 16 є санкціями відносно визначеними. Усі вони мають чітко визначену максимальну межу покарання. В окремих санкціях (ч. 2 ст. 109 КК України, ч. 3 ст. 109 КК України) мінімальна межа покарання не визначена й установлюється 3 урахуванням положень Загальної частини КК України. Закономірності методики встановлення мінімуму та максимуму основного покарання у відносно визначених санкціях досліджуваного розділу ми не досліджували, оскільки це не є безпосередньо предметом дослідження. Але варто підкреслити, що окремі вчені відкрито заявляли про неможливість чіткої аргументації й установлення закономірностей у визначенні верхньої та нижньої меж санкцій [4, с. 53]. Незважаючи на це, у конструкції більшості санкцій розділу I Особливої частини КК України спостерігається плавне «перетікання» строків основного покарання в бік збільшення за наявності в певній статті декількох частин (які є кваліфікуючими, обставини, що містяться в них, обтяжують покарання). Але це питання, на нашу думку, вимагає подальшого й більш глибокого розроблення науковцями, які опікуються проблематикою побудови кримінально-правових санкцій.

Установлено, що майже в усіх випадках (окрім ч. ч. 1, 2 ст. 114-1 КК України), санкції злочинів проти основ національної безпеки є кумулятивними. Як додаткове покарання передбачається конфіскація майна (при чому вона виступає, як правило, у вигляді факультативного додаткового покарання (ч. ч. 1, 2, 3 ст. 109 КК України, ч. ч. 1, 2, 3 ст. 110 КК України, ч. 1 ст. 111 КК України, ст. 112 КК України, ст. 113 КК України, ч. 1 ст. 114 КК України)). Неординарними в цьому випадку є санкції всіх частин ст. 110-2 КК України. Санкції частин цієї статті відрізняються від інших санкцій злочинів проти основ національної безпеки України за декількома ознаками: 1) вони передбачають обов' язковість призначення додаткового покарання; 2) санкції цих частин статей передбачають призначення двох додаткових покарань водночас - заборони обіймати певні посади або займатися певною діяльністю та конфіскацію майна. Виходячи з аналізу складів злочинів, передбачених ст. 110-2 КК України, призначення цих додаткових покарань, особливо заборони обіймати певні посади або займатися певною діяльністю зумовлюється тим, що цей злочин полягає у фінансуванні дій, учинених з метою насильницької зміни чи повалення конституційного ладу або захоплення державної влади, зміни меж території або державного кордону України, а це здебільшого пов'язується 3 обійманням певних посад або зайняттям фінансовою 
діяльністю. Деякі автори щодо цього питання взагалі вважають, що необхідно внести зміни в санкції ст. ст. 109-111 КК України шляхом їх доповнення додатковими покараннями у вигляді обмеження на певний строк права обирати й бути обраними до органів державної влади та місцевого самоврядування (як під час відбування покарання, так і після нього), права на державну службу та службу в органах місцевого самоврядування (після відбуття покарання), незалежно від того обіймала особа таку посаду чи ні [3, с. 142].

Аналіз санкцій розділу I «Злочини проти основ національної безпеки» засвідчив, що загалом формування санкцій відбулося 3 додержанням вимог i принципів побудови санкцій статей Особливої частини КК України, але не без винятків. Серед найбільш типових помилок, що виявляються в конструкції санкції, окремі вчені виділяють такі: 1) у деяких випадках законодавець у різних статтях і навіть у різних частинах однієї статті певний вид покарання називає по-різному; 2) спостерігається певна непослідовність під час визначення видів покарань, тобто відступ від загального правила щодо побудови санкцій, згідно з яким покарання розміщуються від менш до більш суворого; 3) сприймається як суперечність побудова санкції певних статей Особливої частини КК без урахування порядку й особливостей призначення окремих видів кримінальних покарань стосовно певних категорій осіб; 4) видається недоцільним під час визначення меж певних видів покарань у санкціях статей Особливої частини КК України зазначати мінімальні межі, які встановлені в Загальній частині для цього виду покарання; 5) під час конструювання санкцій не завжди беруться до уваги характер і ступінь суспільної небезпечності передбаченого в диспозиції статті злочину, а також особливості суб'єкта злочину, що негативно позначається на судовій практиці; 6) видається необгрунтованим недотримання під час конструювання санкцій правила про допустиме співвідношення визначених у санкції основних і додаткових покарань, згідно з яким основне покарання завжди має бути більш суворим, ніж приєднане до нього додаткове; 7) є недоцільним установлення в санкції великої амплітуди між нижчими та вищими межами покарання у формі позбавлення волі на певний строк; 8) сумнівним є встановлення в санкції значної кількості основних видів покарання, які можуть бути призначені за той самий злочин; 9) не завжди є узгодженими санкції в основному, кваліфікованому й особливо кваліфікованому складах злочинів [2, с. 97]. Як уважається, з усіх вищеперерахованих недоліків конструювання санкцій у досліджуваному нами розділі I КК України «Злочини проти основ національної безпеки» спостерігається лише останній.

Ідея про взаємозалежність санкцій основного та кваліфікованого складів злочину не $є$ новою.
3 розвитком сучасного кримінального права вчені неодноразово висловлювали думку, що вища межа санкції за простий злочин повинна бути водночас нижчою межею санкції за кваліфікований злочин [6, с. 950].

Єдиним моментом, що вимагає додаткового дослідження й аналізу, є порядок установлення санкцій за вчинення кваліфікованих складів у межах ст. 109 КК України, а саме ч. ч. 2 та 3 вказаної статті. За загальними правилами, частини другі, треті тощо статей Особливої частини КК України містять обставини, що є кваліфікуючими, такими, що збільшують суспільну небезпечність діяння й обумовлюють необхідність призначення більш суворого покарання (окрім випадків, коли вказані частини статей є привілейованими). Така сама ситуація спостерігається й щодо положень ч. ч. 2, 3 ст. 109 КК України. Частина 1 указаної статті передбачає відповідальність за таке: «Дії, вчинені з метою насильницької зміни чи повалення конституційного ладу або захоплення державної влади, а також змова про вчинення таких дій». Частина 2 вказаної статті передбачає відповідальність за таке: «Публічні заклики до насильницької зміни чи повалення конституційного ладу або до захоплення державної влади, а також розповсюдження матеріалів із закликами до вчинення таких дій». Частина 3 передбачає відповідальність за таке: "Дії, передбачені частиною другою цієї статті, вчинені особою, яка є представником влади, або повторно, або організованою групою, або з використанням засобів масової інформації». Стосовно ч. 2 вказаної статті дійсно є питання щодо співвідношення за ступенем суспільної небезпечності з діянням, передбаченим ч. 1 указаної статті. Можливо, навіть заклики щодо насильницької зміни чи повалення конституційного ладу є менш суспільно небезпечними, ніж дії, спрямовані на це й змова про вчинення таких дій. У такому разі постає питання про необхідність переформовування положень частин указаної статті в її загальному змісті. Це, на нашу думку, є полем для подальших наукових розвідок.

Але той факт, що вказані дії, учинені особою, яка $€$ представником влади, або повторно, або організованою групою, або з використанням засобів масової інформації, мають більший ступінь суспільної небезпеки, як видається, є беззаперечним. У такому разі постає питання про методику формування санкцій за вчинення діянь, передбачених різними частинами вказаної статті. Нагадаємо, що ч. 1 ст. 109 КК України як санкцію передбачає можливість покарання особи «позбавленням волі на строк від п'яти до десяти років з конфіскацією майна або без такої» . Тобто ця санкція є безальтернативною (про що вказувалося вище). Частини 2 та 3 натомість містять альтернативні санкції - «караються обмеженням волі на строк до трьох років або позбавленням волі на той самий строк $з$ конфіскацією майна або без 
такої», відповідно - «караються обмеженням волі на строк до п'яти років або позбавленням волі на той самий строк з конфіскацією майна або без такої». Той факт, що санкція за вчинення діяння, передбаченого кваліфікованим складом злочину, є менш суворою, ніж санкція, що передбачена за вчинення діяння, зазначеного в ч. 1 досліджуваної статті, як видається, порушує основні принципи побудови санкцій. Про меншу суворість санкції, передбаченої ч. 3 ст. 109 КК України, свідчить те, що вона передбачає (на відміну від ч. 1 ст. 109 КК України) можливість призначення як альтернативи позбавленню волі на певний строк менш суворе покарання у вигляді обмеження волі. Уважаємо, що цей підхід є недоцільним і вимагає змін конструкції санкцій відповідних частин ст. 109 КК України.

\section{Jimepamypa}

1. Вечерова Є.М. Кримінально-правові санкції крізь призму основних векторів сучасної кримінальної політики України (критичний аналіз деяких новел Кримінального кодексу України). Наук. вісн. Міжнар. гуланітарного ун-ту. Серія «Юриспрудениія». 2015. № 13. Tom 2. С. $64-66$. С. 65 .

2. Горох О.П. Проблеми конструювання санкцій спеціальних кримінально-правових норм. Наукові за писки НаУКМА. 2009. Т. 90 : Юридичні науки. С. 94-98.

3. Дячок 0.0. Щодо законодавчого обмеження правового статусу осіб, які вчинили злочини проти основ національної безпеки України. Правова позиція. 2017. № 2 (19). С. 138-150. С. 142.

4. Наумов А. Камни преткновения уголовного наказания. Российская юстииия. 2002. № 9. С. 53-54. C. 53.

5. Рубащенко М.А. Забезпечення основ національної безпеки України кримінально-правовими заходами. Сталий розвиток 2030: правова, еконолічна, соціальна, екологічна та політична складові : матеріали доповідей Міжнародної міждисциплінарної конференції (Будапешт, Угорщина). Будапешт, 2017. 160 c. C. 121-124. C. 122. URL: http://dspace.nlu.edu.ua/ bitstream/123456789/14472/1/Rubashenko_121-124. pdf.

6. Ткачук О.Ю. Принципи побудови кримінально-правових санкцій. Держава і право. Вип. 44. C. 588-591. С. 588 .

\section{Анотація}

Єна I. O. Санкції за злочини проти основ національної безпеки України: окремі закономірності та проблеми побудови. - Стаття.

У статті розглядається проблематика побудови санкцій за вчинення злочинів проти основ національної безпеки України. Констатується, що в наукових працях сучасних учених приділяється недостатня увага дослідженню особливостей призначення покарання за злочини проти основ національної безпеки України. Також автор на грунті досліджених наукових праць стверджує, що, незважаючи на велику різноманітність наукових робіт, присвячених санкціям та особливостям ïx побудови, питання їх архітектури не є остаточно вирішеним. Стверджується, що методологічно правильним під час дослідження порядку призначення покарання за вчинення певної групи злочинів є першочергова наукова розвідка системи санкцій за злочини такого роду. На основі аналізу чинного законодавства про кримінальну відповідальність здійснюється класифікація санкцій за злочини проти основ національної безпеки та виокремлюються основні тенденції їх побудови. Визначено, що більшість санкцій є альтернативними, відносно визначеними та кумулятивними. Найбільш розповсюдженим покаранням, що передбачено за вчинення злочинів проти основ національної безпеки, є позбавлення волі на певний строк, як додаткове покарання передбачається конфіскація майна, що видається автору досить доречним. Визначається, що загалом побудова санкцій досліджуваної групи злочинів здебільшого відповідає загальним вимогам і принципам побудови санкцій. При цьому виділяються окремі моменти, що потребують подальшого дослідження, можливі зміни до чинного законодавства та аргументація їх упровадження. Звертається увага на необхідність чіткої взаємодії та взаємовідношення санкцій простого та кваліфікованого складів злочинів, що передбачаються ч. ч. 1 і 2 (3, 4 тощо) відповідних складів злочину. Уважається за необхідне здійснювати поступове зростання меж покарань у відповідних санкціях, зважаючи на зростання рівня суспільної небезпеки.

Ключові слова: національна безпека, санкції, призначення покарання.

\section{Summary}

Yena I. O. Approvals for crimes against bases of national safety of Ukraine: separate conformities to law and problems of construction. - Article.

In the article the range of problems of construction of approvals is examined for committing crime against bases of national safety of Ukraine. Established, that in scientific works of modern scientists insufficient attention is spared to research of features of awarding punishment for crimes sweats of bases of national safety of Ukraine. Also, author on base of investigational scientific works, asserts that, without regard to the large variety of the advanced studies to the devoted approvals and features of their construction, question of their architecture is not finally decided. It becomes firmly established that methodologically faithful at research of order of awarding punishment for the feasance of certain group of crimes, there is near-term scientific secret service of the system of approvals for crimes such. On soil of analysis of current legislation about criminal responsibility, classification of approvals comes true on crimes against bases of national safety and the basic tendencies of their construction are distinguished. Certainly, that most approvals are alternative, relatively certain and cumulative. By the most widespread punishment, that it is envisaged for committing crime against bases of national safety of imprisonment on a certain term, confiscation of property that seems to the author appropriate enough is envisaged in quality of additional punishment. It is determined that on the whole, construction of approvals of the investigated group of crimes, mostly answers general requirements and principles of construction of approvals. Separate moments that need further research, possible changes to the current legislation and argumentation of their introduction, are thus distinguished. Attention applies on the necessity of clear cooperation and interrelation of approvals of simple and skilled syllables of crimes that is envisaged p. 1 and p. $2(3,4 \mathrm{ps}$.) corresponding syllables of crime. It is considered a necessity to carry out the gradual increase of limits of punishments in corresponding approvals having regard to the increase of level of public danger.

Key words: national safety, approvals, awarding punishment. 